\title{
Clinicopathological Study on Hepatitis C Virus-associated Glomerulonephritis without Hepatitis C Virus in the Blood
}

\author{
Hideaki Yamabe ${ }^{1,2}$, Norio Nakamura ${ }^{1}$, Michiko Shimada ${ }^{1}$, Reiichi Murakami ${ }^{1}$, \\ Takeshi Fujita ${ }^{1}$, Yuko Shimaya ${ }^{1}$, Maiko Kitajima ${ }^{2}$ and Mayumi Urushizaka ${ }^{2}$
}

\begin{abstract}
Purpose Patients with hepatitis C virus (HCV)-associated glomerulonephritis in whom HCV RNA was not detected in the blood have been reported. We attempted to uncover the differences between HCV RNAnegative and HCV RNA-positive cases.

Methods The clinical and pathological findings for 5 patients with $\mathrm{HCV}$-associated glomerulonephritis without $\mathrm{HCV}$ in the blood were compared with those for 23 patients with HCV RNA-positive HCVassociated glomerulonephritis.

Results The HCV RNA-negative cases were characterized by advanced age, female dominance, no cryoglobulinemia and no glomerular deposition of IgG compared with the HCV RNA-positive cases, although no differences were observed in amount of urinary protein, frequency of nephrotic syndrome, serum levels of total protein, creatinine level, presence of hypocomplementemia and rheumatoid factor. The prognosis was similar for both groups.
\end{abstract}

Conclusion These cases point to the need for further study of the pathogenesis of this disease.

Key words: hepatitis C, MPGN, HCV RNA, cryoglobulin

(Inter Med 49: 1321-1323, 2010)

(DOI: 10.2169/internalmedicine.49.3596)

\section{Introduction}

The pathogenesis of primary glomerulonephritis, such as membranous nephropathy, IgA nephropathy and membranoproliferative glomerulonephritis (MPGN), is not yet fully understood. It is generally accepted that most of these diseases are caused by immune complexes as well as acute post-streptococcal glomerulonephritis, because the glomerular deposition of $\operatorname{IgG}$ or $\operatorname{IgA}$ together with a complement is usually observed in these diseases, and it has been found experimentally that immune complexes can induce glomerulonephritis in animals. In 1993, Johnson et al first described 8 patients with MPGN and hepatitis $\mathrm{C}$ virus (HCV) infection (1). Most of the cases showed nephrotic syndrome, hypocomplementemia, serum IgM rheumatoid factor and cryoglobulinemia. Interferon alpha has been approved for use in the treatment of chronic $\mathrm{HCV}$ infection. Many investigators have reported that interferon alpha lowers urinary protein concomitant with the disappearance of HCV RNA in HCVassociated glomerulonephritis $(2,3)$. These reports suggest that $\mathrm{HCV}$ is very important as an antigen. Recently, we encountered 5 cases of $\mathrm{HCV}$-associated glomerulonephritis in whom HCV RNA was not detected in the blood in the absence of interferon therapy. Therefore, we sought to uncover the differences between HCV RNA-negative cases and HCV RNA-positive ones.

\section{Methods}

The subjects were 28 patients who underwent renal biopsy and were diagnosed as having HCV-associated glomerulonephritis in our hospital between 1991 and 2007. The diagnosis of $\mathrm{HCV}$-associated glomerulonephritis was made by finding of positive serum HCV antibody, MPGN histologically, and glomerular C3 deposition. A few cases of

${ }^{1}$ Department of Nephrology, Hirosaki University Graduate School of Medicine, Hirosaki and ${ }^{2}$ Hirosaki University Graduate School of Health Sciences, Hirosaki

Received for publication February 27, 2010; Accepted for publication April 2, 2010

Correspondence to Dr. Hideaki Yamabe, yamabe@cc.hirosaki-u.ac.jp 
membranous nephropathy were excluded from this study. The clinical and pathological features of the 28 patients were examined. Serum HCV antibody was evaluated in all cases at the same time as the renal biopsy, utilizing $\mathrm{HCV}$ EIA Abbott (Dinabot, Tokyo, Japan), which detects antibody to the antigen c100-3, until April 1992 and then by HCV PHA Abbot second generation assay, which measures antibodies to the c100-3, pHCV34 (core), and pHCV31 (NS 3 4) antigens. Recently, chemiluminescent enzyme immunoassay Abbot second generation has been used. Patients with positive $\mathrm{HCV}$ antibody were further examined for the presence of HCV RNA in their serum by RT-PCR (Roche Diagnostics, Tokyo, Japan) until 2007. The patients gave informed consent for this study.

Statistically chi square test and Fisher's exact test were used and $\mathrm{p}<0.05$ was considered statistically significant.

\section{Results}

HCV RNA was not detected in the blood of 5 of the 28 patients. The clinical data of the $5 \mathrm{HCV}$ RNA-negative cases are shown in Table 1. The mean age was 71.0 \pm 8.3 years, and they included 1 male and 4 females. The clinical findings were compared with those for $\mathrm{HCV}$-positive patients (Table 2). Advanced age, female dominance and no cryoglobulinemia were observed in the HCV RNA-negative cases, but the other clinical findings were the same as those for the HCV RNA-positive cases. The HCV RNA-negative cases showed MPGN, just like the HCV RNA-positive

Table 1. Clinical Data of 5 Patients with $\mathrm{HCV}$ RNA Negative MPGN

\begin{tabular}{|c|c|c|c|c|c|}
\hline Patient No. & 1 & 2 & 3 & 4 & 5 \\
\hline Age & 61 & 82 & 72 & 75 & 65 \\
\hline Sex & female & female & male & female & female \\
\hline $\begin{array}{l}\text { Nephrotic } \\
\text { syndrome }\end{array}$ & $(-)$ & $(+)$ & $(+)$ & $(-)$ & $(-)$ \\
\hline $\begin{array}{l}\text { Urinary protein } \\
\text { (g/day) }\end{array}$ & 1.15 & 5.5 & 4 & 3.82 & 1.62 \\
\hline $\begin{array}{l}\text { Serum } \\
\text { Creatinine } \\
\text { (mg/dL) }\end{array}$ & 0.9 & 2.4 & 1.2 & 1.7 & 0.9 \\
\hline $\mathrm{C} 3(\mathrm{mg} / \mathrm{dL})$ & 61 & 97 & 86 & 83 & 94 \\
\hline $\mathrm{C} 4(\mathrm{mg} / \mathrm{dL})$ & 2 & 19 & 22 & 26 & 17 \\
\hline Cryoglobulin & $(-)$ & $(-)$ & $(-)$ & $(-)$ & $(-)$ \\
\hline $\begin{array}{l}\text { Rheumatoid } \\
\text { factor }\end{array}$ & $(+)$ & $(+)$ & $(-)$ & $(-)$ & $(-)$ \\
\hline Prognosis & stable & died & remission & stable & stable \\
\hline
\end{tabular}

cases. No difference was observed between HCV RNAnegative cases and HCV RNA-positive cases in the degree of glomerular and tubulointerstitial lesions. However, neither glomerular $\mathrm{IgG}$ nor IgA deposition was demonstrated in any of the HCV RNA-negative patients (Table 3). Naturally, cryoglobulin was not observed by electron microscopy in the HCV RNA-negative cases.

\section{Discussion}

The observation that most patients with $\mathrm{HCV}$ infection continue to have HCV RNA detectable in their serum despite a strong humoral immune response (4) suggests that these patients may be at risk for chronic immune complexassociated diseases. This is supported by several findings according to which HCV may be a major cause of essential mixed cryoglobulinemia $(5,6)$. The majority of patients with essential mixed cryoglobulinemia have HCV RNA and $\mathrm{HCV}$ antibody in their blood, and the HCV RNA and HCV antibody can be shown to be concentrated in the cryoglobulins (5).

We first observed that chronic HCV infection may also be associated with acute glomerulonephritis that histologically resembles MPGN I. These patients may or may not have cryoglobulinemia, and even if it is present, they frequently lack other symptoms of essential mixed cryoglobulinemia, such as purpura or arthralgia (1). The efficacy of interferon alpha in the treatment of these patients suggests the importance of $\mathrm{HCV}$ as an antigen.

We previously encountered 2 cases with $\mathrm{HCV}$-associated glomerulonephritis in whom HCV RNA was not detected in the blood (7). We report here the clinical and pathological data for $5 \mathrm{HCV}$ RNA-negative cases compared with those for HCV RNA-positive cases. HCV RNA was not demonstrated in 5 of $28(17.9 \%)$ patients within a period of 17 years in our hospital. However, the histological findings were the same as those for the HCV RNA-positive cases. Clinically, the HCV RNA-negative cases were similar to the HCV RNA-positive ones except that the former were of more advanced age, female dominance and showed no cryoglobulinemia. In the immunofluorescence study, $\operatorname{IgM}$ and C3 were positive in all $5 \mathrm{HCV}$ RNA-negative cases, although $\operatorname{IgG}$ and $\operatorname{IgA}$ were negative.

It is well known that some patients (10-67\%) with $\mathrm{HCV}$

Table 2. Comparison of Clinical Findings between HCV RNA Negative and Positive MPGN $(* \mathbf{p}<0.05)$

\begin{tabular}{llll}
\hline & \multicolumn{1}{c}{$\begin{array}{c}\text { HCV RNA Negative } \\
(\mathrm{n}=5)\end{array}$} & $\begin{array}{c}\text { HCV RNA Positive } \\
(\mathrm{n}=23)\end{array}$ \\
\hline Age & $71.0 \pm 8.3$ & $58.7 \pm 10.8$ & $\mathrm{p}<0.02 *$ \\
\hline Female/Male & $4 / 1$ & $6 / 17$ & $\mathrm{p}<0.04 *$ \\
\hline Nephrotic Syndrome & $2 / 5(40 \%)$ & $16 / 23(70 \%)$ & $\mathrm{p}=0.32$ \\
\hline Cryoglobulinemia & $0 / 5(0 \%)$ & $20 / 23(87 \%)$ & $\mathrm{p}<0.006 *$ \\
\hline Urinary Protein $(\mathrm{g} /$ day $)$ & $3.2 \pm 1.82$ & $5.79 \pm 3.90$ & $\mathrm{p}=0.17$ \\
\hline Total Protein $(\mathrm{g} / \mathrm{dL})$ & $5.64 \pm 0.87$ & $5.52 \pm 1.12$ & $\mathrm{p}=0.83$ \\
\hline Serum Creatinine $(\mathrm{mg} / \mathrm{dL})$ & $1.46 \pm 0.62$ & $1.66 \pm 1.23$ & $\mathrm{p}=0.73$ \\
\hline Hypocomplementemia & $1 / 5(20 \%)$ & $10 / 23(43.5 \%)$ & $\mathrm{p}=0.62$ \\
\hline Rheumatoid Factor & $2 / 5(40 \%)$ & $13 / 17(76.4 \%)$ & $\mathrm{p}=0.27$ \\
\hline Prognosis (died or hemodialysis) $1 / 5(20 \%)$ & $14 / 23(60.9 \%)$ & $\mathrm{p}=0.15$ \\
\hline
\end{tabular}


Table 3. Comparison of Histological Findings between HCV RNA Negative and Positive MPGN $(* \mathbf{p}<0.05)$

\begin{tabular}{llll}
\hline & & HCV RNA & HCV RNA \\
& Negative $(n=5)$ & Positive $(n=23)$ \\
\hline Light Microscopy & & & \\
\hline MPGN & $5 / 5(100 \%)$ & $23 / 23(100 \%)$ & $\mathrm{p}>0.99$ \\
\hline Immunofluorescence Study & & \\
\hline IgG & $0 / 5(0 \%)$ & $15 / 23(65.2 \%)$ & $\mathrm{p}=0.013 *$ \\
\hline IgA & $0 / 5(0 \%)$ & $11 / 23(47.8 \%)$ & $\mathrm{p}=0.125$ \\
\hline IgM & $5 / 5(100 \%)$ & $21 / 23(91.3 \%)$ & $\mathrm{p}>0.99$ \\
\hline C3 & $5 / 5(100 \%)$ & $23 / 23(100 \%)$ & $\mathrm{p}>0.99$ \\
\hline Electron Microscopy & & & \\
\hline Subendothelial deposition & $3 / 3(100 \%)$ & $11 / 11(100 \%)$ & $\mathrm{p}>0.99$ \\
\hline Cryoglobulin deposition & $0 / 3(0 \%)$ & $7 / 11(63.6 \%)$ & $\mathrm{p}=0.192$ \\
\hline
\end{tabular}

infection achieve spontaneous virological recovery (8). Gerlach et al have reported that the spontaneous clearance of $\mathrm{HCV}$ was observed in $24(52 \%)$ of 46 patients with acute symptomatic hepatitis $\mathrm{C}$ within 12 weeks after the onset of symptoms (9). Therefore, our 5 patients may be in a state of convalescence after the disappearance of $\mathrm{HCV}$ from their blood. On the other hand, IgM-type rheumatoid factor is sometimes demonstrated in $\mathrm{HCV}$-associated glomeru- lonephritis, and it binds preferentially to anti-HCV IgG instead of normal human $\operatorname{IgG}(1)$. Therefore, the immune complex may consist only of an anti-HCV antibody, and the IgM-type rheumatoid factor or the IgM-type rheumatoid factor itself may play the role of antigen. Thirdly Pham et al have examined the existence of HCV RNA by a highly sensitive RT-PCR-nucleic acid hybridization assay in the sera and peripheral blood mononuclear cells of 16 patients with spontaneous or treatment-induced resolution. They reported that traces of the HCV RNA-negative strand, suggesting progressive virus replication, were detected in the majority of the mitogen-stimulated peripheral blood mononuclear cells (10). Therefore, we may not be able to exclude the possibility of an immune complex which includes HCV. The fourth possibility is that the disease is not due to $\mathrm{HCV}$, and MPGN occurred in the patients who had suffered from hepatitis $\mathrm{C}$ by chance.

It is unknown why MPGN occurs in HCV RNA-negative patients. These cases point to the need for further study of the pathogenesis of $\mathrm{HCV}$-associated glomerulonephritis.

\section{References}

1. Johnson RJ, Gretch DR, Yamabe H, et al. Membranoproliferative glomerulonephritis associated with hepatitis $\mathrm{C}$ virus infection. $\mathrm{N}$ Engl J Med 328: 465-470, 1993.

2. Johnson RJ, Gretch DR, Couser WG, et al. Hepatitis C virusassociated glomerulonephritis. Effect of $\alpha$-interferon therapy. Kidney Int 46: 1700-1704, 1994.

3. Yamabe H, Johnson RJ, Gretch DR, et al. Membranoproliferative glomerulonephritis associated with hepatitis $\mathrm{C}$ virus infection responsive to interferon-alpha. Am J Kidney Dis 25: 67-69, 1995.

4. Alter MJ, Margolis HS, Krawczynski K, et al. The natural history of community-acquired hepatitis $\mathrm{C}$ in the United States. The Sentinel Counties Chronin non-A, non-B Hepatitis Study Team. N Engl J Med 327: 1899-1905, 1992.

5. Agnello V, Chung RT, Kaplan LM. A role for hepatitis $C$ virus infection in type II cryoglobulinemia. N Engl J Med 327: 14901495, 1992.

6. Misiani R, Bellavita P, Fenili D, et al. Hepatitis C virus infection in patients with essential mixed cryoglobulinemia. Ann Intern Med 117: 573-577, 1992.

7. Yamabe H, Nakamura N, Nakamura N, et al. Hepatitis C virusassociated glomerulonephritis without hepatitis $\mathrm{C}$ virus in the blood. Am J Kidney Dis 46: E65-E69, 2005.

8. Pimstone NR, Pimstone D, Saicbeur T, Powell J, Yu AS. "Waitand See": An alternative approach to managing acute hepatitis C with high-dose interferon- $\alpha$ monotherapy. Ann Intern Med 141: W 91-W92, 2004.

9. Gerlach JT, Diepolder HM, Zachoval R, et al. Acute hepatitis C: high rate of both spontaneous and treatment-induced viral clearance. Gastroenterol 125: 80-88, 2003.

10. Pham TN, MacParland SA, Mulrooney PM, Cooksley H, Naoumov NV, Michalak TI. Hepatitis C virus persistence after spontaneous or treatment-induced resolution of hepatitis C. J Virol 78: 5867-5874, 2004.

(C) 2010 The Japanese Society of Internal Medicine http://www.naika.or.jp/imindex.html 